\title{
PENINGKATAN PEMAHAMAN SISWA TENTANG ALAT PENCERNAAN MAKANAN MELALUI MEDIA GAMBAR/ MODEL BAGI KELAS V DI SD INPRES 118 KLAMALU
}

\author{
MARSYE W.TAPILATU
}

SD Inpres 118 Klamalu Kabupaten Sorong

\begin{abstract}
ABSTRAK
Penelitian ini bertujuan untuk mengetahui peningkatanPemahaman siswa akan Alat Pencernaan Makanaan bagi siswa Kelas V di SD Inpres 118 Klamalu melalui Model / Gambar. Jenis penelitian ini adalah penelitian tindakan kelas (Classroom Action Research) yang dilakukan secara kolaboratif antara peneliti dengan guru. Penelitian dilaksanakan dalam dua siklus, masing-masing siklus terdiri dari empat komponen yaitu perencanaan, tindakan, pengamatan dan refleksi. Teknik pengumpulan data yang digunakan dalam penelitian ini adalah wawancara, observasi, dokumentasi dan tes. Analisis data dilakukan dalam 3 tahap yaitu reduksi, penyajian data serta menarik kesimpulan. Hasil penelitian menunjukkan 1 nilai rata-rata pemahaman siswa akan alat pencernaan siswa kelas $\mathrm{V}$ pada sebelum siklus sebesar 60 pada siklus I sebesar 68,76 dan pada siklus II sebesar 78,57 sehingga terdapat kenaikan nilai rata- rata dari sebelum siklus I. Selanjutnya kesiklus II. 2. Prosentase ketuntasan belajar siswa pada prasiklus menunjukan angka sebesar 38,09\% (8 siswa tuntas dalam belajarnya dari seluruh peserta 21 siswa ) ,pada siklus I sebesar 68,76 \% (10 siswa tuntas dalam belajarnya dari seluruh peserta 21 siswa ) dan pada siklus II sebesar 78,57 \% ( 20 siswa tuntas dalam belajarnya dari seluruh peserta 21 siswa ) Dengan demikian terdapat penningkatan ketuntasan belajar siswa dari siklus I ke siklus II .Berdasarkan keterangan di atas maka dapat dibuat su/ kesimpulan sebagai berikut : Melalui Pemanfaatan gambar / model dapat meningkatkan pemahan siswa akan alat pencernaan pada siswa kelas V SD Inpres 118 Klamalu Distrik Mariat KabupAten Sorong tahun pelajaran $2011 / 2012$
\end{abstract}

Kata kunci : Pemahaman, Pencernaan, Model

This study aims to determine the increase in students' understanding of food digestion tools for grade V students at SD Inpres 118 Klamalu through models / pictures. This type of research is a Classroom Action Research conducted collaboratively between researchers and teachers. The study was conducted in two cycles, each cycle consisting of four components, namely planning, action, observation and reflection. Data collection techniques used in this study were interviews, observation, documentation and tests. Data analysis was carried out in 3 stages namely reduction, presentation of data and drawing conclusions. The results showed that the average value of students' understanding of digestion tools of class V students before the cycle of 60 in the first cycle was 68.76 and in the second cycle was 78.57 so that there was an increase in the average value from before the first cycle. Furthermore, the cycle II. 2. The percentage of students' mastery learning in pre-cycle shows a figure of $38.09 \%$ (8 students complete their learning from all participants 21 students), in the first cycle of 68.76\% (10 students complete their learning from all participants 21 students) and at cycle II of 78.57\% (20 students complete their learning from all participants 21 students) Thus there is an increase in student learning completeness from cycle I to cycle II. Based on the information above, conclusions can be made as follows: Through the use of pictures / the model can improve students' digestion of digestive equipment in fifth grade students of SD Inpres 118 Klamalu Mariat District, Sorong Regency, Sorong academic year 2011/2012

Keywords: Understanding, Digestion, Model

\section{PENDAHULUAN}

Pembelajaran IPA yang berlangsung saat ini menurut pengamatan penulis terkesan belum maksimal.Hal ini dari beberapa indikator antara lain hasil tes semester yang kurang dari KKM (Kriteria Ketuntasan Minimal), pengakuan siswa secara obyektif bahwa IPA termasuk dalam kategori sulit menurut mereka disamping Matematika dan IPS

Kenyataan di kelas dalam pelaksanaan proses belajar mengajar IPA ada saja tingkah laku anak yang kadang kala tidak sesuai dengan harapan guru, Seperti bergurau dengan teman saat di terangkan, tidak mengerjakan PR, tidak mau membuat catatan, tidak mau memperhatikan saat diterangkan dan lain sebagainya.

Gejala tersebut sedikit banyak akan mempengaruhi proses pembelajaran di kelas. Perilaku yang ditunjukkan sebagian anak tersebut merupakan suatu tindakan yang negatif yang akan menghambat pencapaian prestasi belajar.

Melihat realita di atas maka guru harus dapat melaksanakan perbaikan sistem pembelajaran, selama ini pembelajaran IPA yang dilaksanakan tanpa menggunakan alat peraga kurang menarik perhatian siswa, sehingga menyebabkan rendahnya prestasi belajar siswa. Dari berbagai sumber dijelaskan bahwa siswa Sekolah Dasar belajar secara holistik (menyeluruh).Konsep yang abstrak harus dikongkritkan dengan media yang tentunya menarik minat peserta didik mengikuti pelajaran sekaligus untuk mendalaminya. Kita memahami bahwa media 
pembelajaran saat ini telah berkembang dengan pesat, namun karena keterbatasan yang dimiliki SD Inpres 45 maka guru kelas pada mata pelajaran IPA yang ada di sekolah tersebut harus pandai-pandai memanfaatkan sarana yang ada di sekitar sekolah untuk membuat pembelajaran lebih menarik. Namun belum semua guru mampu memanfaatkan sarana ynag ada disekitar sekolah untuk proses belajar mengajara bahkan cenderung tidak pernah digunakan dalam pembelajaran di kelas.

Untuk mengetahui benar tidaknya media lingkungan sekitar sekolah dapat meningkatkan pemahaman anak akan peristiwa fotosintesis maka perlu diadakan penelitian, yang selanjutnya penelitian ini diberikan judul Peningkatan pemahaman siswa akan hasil fotosintesis melalui pemanfaatan lingkungan sekitar sekolah pada siswa kelas V SD Inpres 118 Klamalu Distrik Mariat Kabupaten Sorong. Tujuan penelitian yang akan dicapai dalam penelitian ini adalah 1). Membuktikan bahwa dengan model / gambar dapat meningkatkan motivasi belajar IPA pada siswa Kelas V SD Inpres 118 Klamalu Kabupaten Sorong tahun 2011/20102. 2) Membuktikan bahwa dengan model / gambar dapat meningkatkan pemahaman siswa akan alat pencernaan makanan pada siswa Kelas V SD Inpres 118 Klamalu Kabupaten Sorong.

\section{METODE PENELITIAN}

Penelitian ini merupakan penelitian tindakan kelas (classroom action research), yaitu pencermatan terhadap kegiatan belajar berupa sebuah tindakan, yang sengaja dimunculkan dan terjadi dalam sebuah kelas secara bersama. Dalam pelaksanaannya peneliti dapat melakukan penelitian tindakan kelas secara mandiri /pun kolaboratif, akan tetapi tidak boleh menghambat kegiatan utama guru dalam proses pembelajaran.

Penelitian ini dilakukan secara kolaboratif dan partisipatif. Secara partisipatif bersama-sama mitra peneliti melaksanakan penelitian ini langkah demi langkah. Selain partisipatif, peneliti dapat berkolaborasi dengan guru Standar Kompetensi Menangani mata pelajaran dengan tujuan memperbaiki kekurangan-kekurangan dalam praktik pembelajaran. Dalam penelitian tindakan kelas ini, guru bertindak sebagai pelaksana tindakan sedangkan peneliti bertindak sebagai kolaborator. Penelitian dilaksanakan di SD Inpres 118 Klamalu yang beralamat di Jl Tuturaga Klamalu Distrik Mariat Kabupaten Sorong. Subjek dalam penelitian ini adalah siswa kelas SD Inpres 118 Klamalu. Sedangkan yang menjadi objek penelitian adalah pemahaman siswa akan alat pencernaan makanan dengan pemanfaatan model/gambar.

Variabel penelitian adalah objek penelitian yang menjadi pusat perhatian selama penelitian berlangsung dan penyusunan laporan. Dalam penelitian ini, yang menjadi variabel utama adalah partisipasi aktif, prestasi belajar dan model /gambar

Instrumen yang dipakai adalah observasi, wawancara, tes, dan teknik dokumentasi

Instrumen yang digunakan dalam penelitian ini adalah catatan lapangan, lembar observasi, panduan wawancara, dan dokumentasi

Penelitian ini dilakukan dalam bentuk siklus, masing-masing siklus terdiri dari perencanaan, tindakan, pengamatan dan refleksi.

Untuk dapat mengetahui keabsahan data dalam penelitian, peneliti menggunakan teknik triangulasi. Triangulasi merupakan teknik pemeriksaan keabsahan data yang memanfaatkan sesuatu yang lain di luar data itu untuk keperluan pengecekan / sebagai pembanding terhadap data itu. Dalam penelitian ini, peneliti mengecek kebenaran data yang diperoleh dari lembar observasi dalam proses pembelajaran, hasil wawancara dan dokumentasi yang dilaksanakan dengan siswa dan guru pada akhir tindakan untuk mempermudah dalam penarikan kesimpulan.

Pada penelitian ini, triangulasi yang digunakan adalah triangulasi sumber dan triangulasi metode: Triangulasi Sumber dan Triangulasi Metode

Analisis data yang digunakan dalam penelitian ini dilakukan terus menerus selama pengumpulan data berlangsung sampai pada akhir penelitian / penarikan kesimpulan. Peneliti merefleksi hasil observasi terhadap proses pembelajaran yang dilaksanakan guru dan siswa di dalam kelas. Adapun yang dianalisis, adalah Partisipasi aktif siswa dan Prestasi Belajar Siswa.

Dari semua siklus yang telah dilakukan maka dapat dikatakan berhasil apabila partisipasi dan prestasi belajar siswa meningkat dan apabila belum memenuhi target maka akan dilanjutkan ke siklus berikutnya. Partisipasi aktif siswa dikatakan berhasil jika partisipasi belajar 75\% siswa dan Prestasi belajar siswa dikatakan berhasil jika prestasi belajar 75\% siswa pada akhir siklus telah mencapai 75 .

\section{PEMBAHASAN}

Dari hasil pengamatan yang dilakukan oleh peneliti, prestasi belajar pada mata pelajaran IPA Siswa kelas Vdi SD Inpres 118 Klamalu dikatakan rendah karena masih ada 13 siswa yang nilainya di bawah 75 yang merupakan Kriteria Ketuntasan Minimal (KKM) yang telah ditentukan sekolah dengan melihat hasil ulangan harian. Hal ini disebabkan guru masih menggunakan metode ceramah dan monoton sehingga siswa menjadi pasif dan kurang aktif dalam mengikuti proses pembelajaran. Hal ini apabila tidak ditindaklanjuti tentu akan mengakibatkan proses pembelajaran tidak optimal dan mempengaruhi prestasi belajar.

Hasil dari lembar pengamatannya ditampilkan pada Tabel 3.1. Dari tabel dapat diketahui bahwa siswa yang mendengarkan penjelasan sebanyak 42,85 \%, mencatat penjelasan 13,61\%, memperhatiakan pembelajar 66,6\%, bertanya 23,8 \%., menjawab pertanyaan 52,3\%, mengeluarkan pendapat 23,8\%, menghargai pendapat teman 61,90\%, mampu menjelaskan kembali 14,28\%.

Tabel 3.1. Hasil Observasi Partisipasi Aktif Siswa pada Siklus 1 


\begin{tabular}{|c|c|c|c|}
\hline \multirow[t]{2}{*}{ Aspek yang diamati } & 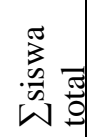 & $\frac{\pi}{3}$ & 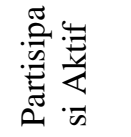 \\
\hline & & & $\%$ \\
\hline $\begin{array}{l}\text { Mendengarkan } \\
\text { Penjelasan }\end{array}$ & 21 & 9 & $42,85 \%$ \\
\hline Mencatat penjelasan & 21 & 10 & $47,61 \%$ \\
\hline $\begin{array}{l}\text { Memperhatikan } \\
\text { pembelajaran }\end{array}$ & 21 & 14 & $66.6 \%$ \\
\hline Bertanya & 21 & 8 & $38,09 \%$ \\
\hline Menjawab pertanyaan & 21 & 11 & $52,3 \%$ \\
\hline Mengeluarkan pendapat & 21 & 5 & $23,8 \%$ \\
\hline $\begin{array}{l}\text { Menghargai pendapat } \\
\text { teman }\end{array}$ & 21 & 13 & $61,90 \%$ \\
\hline $\begin{array}{ll}\text { Mampu } & \text { menjelaskan } \\
\text { kembali } & \\
\end{array}$ & 21 & 3 & $14,28 \%$ \\
\hline
\end{tabular}

Pada pelaksanaan pembelajaran menggunakan pemanfatan lingkungan sekitar sekolah untuk meningkatkan partisipasi aktif siswa pada siklus 1 belum sepenuhnya terlaksana dengan baik. Hal ini terjadi, mungkin dikarenakan siswa masih canggung dengan pembelajaran menggunakan pemanfaatan lingkungan sekitar sekolah,

Prestasi belajar pada siklus 1 juga belum menunjukkan hasil yang maksimal, meskipun telah banyak siswa yang memenuhi kriteria ketuntasan minimal tetapi masih ada juga siswa yang belum memenuhi.

Berdasarkan hasil refleksi tersebut, maka perlu adanya tindakan lanjutan untuk memperbaiki / menyempurnakan pembelajaran dengan menggunakan pemanfaatan lingkungan sekitar sekolah. Dikarenakan belum tercapainya target tindakan yang diinginkan pada pelaksanaan tindakan pada siklus 1 , maka peneliti dan guru sepakat untuk melanjutkan tindakan pada siklus II.

Hasil dari pengamatan siswa pada siklus II, dapat dilihat pada Tabel 3.2. Dari tabel 3.2. dapat diketahui bahwa siswa yang mendengarkan penjelasan sebanyak 80,95.\%, mencatat penjelasan 90,47\%, memperhatikan pembelajaran $76,19 \%$, bertanya $71,42 \%$, menjawab pertanyaan $85,7 \%$, mengeluarkan pendapat 38,09\%, menghargai pendapat teman 95,23.\%, mampu menjelaskan kembali 71,4 .\%.

Tabel 3.2. Hasil Observasi Partisipasi Aktif Siswa pada Siklus 2

\begin{tabular}{|c|c|c|c|}
\hline \multirow[b]{2}{*}{ Aspek yang diamati } & \multicolumn{2}{|c|}{ Esiswa total } & \multirow{2}{*}{$\begin{array}{l}\text { Partisip } \\
\text { asi } \\
\text { Aktif }\end{array}$} \\
\hline & $\sum$ siswa & $\%$ & \\
\hline Mendengarkan Penjelasan & 21 & 17 & $80,95 \%$ \\
\hline Mencatat penjelasan & 21 & 21 & $100 \%$ \\
\hline $\begin{array}{l}\text { Memperhatikan } \\
\text { pembelajaran }\end{array}$ & 21 & 16 & $76,19 \%$ \\
\hline Bertanya & 21 & 15 & $71,42 \%$ \\
\hline Menjawab pertanyaan & 21 & 15 & $71,42 \%$ \\
\hline Mengeluarkan Pendapat & 21 & 9 & $42,85 \%$ \\
\hline $\begin{array}{l}\text { Menghargai Pendapat } \\
\text { teman }\end{array}$ & 21 & 20 & $95,23 \%$ \\
\hline
\end{tabular}

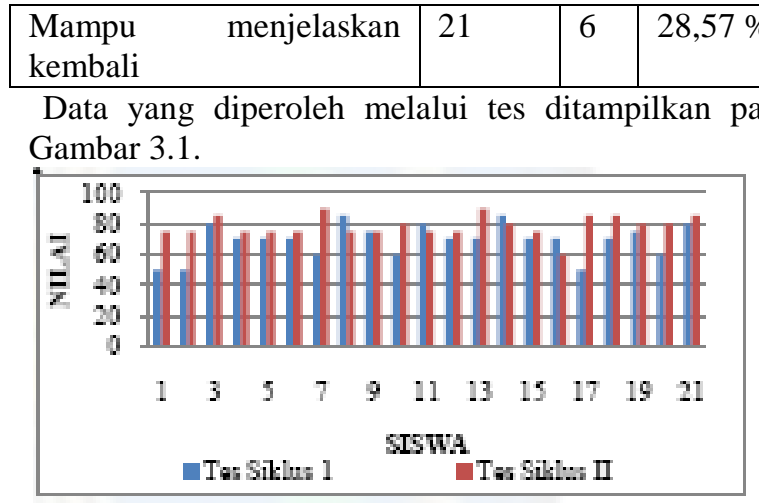

Gambar 3.1. Hasil tes

Pada hasil partisipasi aktif siswa, siswa telah berpartisipasi secara aktif dalam pembelajaran dan keaktifan siswa pada proses pembelajan berlangsung dapat dilihat pada dokumentasi berupa foto-foto yang telah terlampir dalam lampiran, sedangkan pada hasil belajar semua siswa sudah mencapai ketuntasan yang telah ditetapkan yaitu memperoleh nilai $\geq 75$ untuk masing-masing siswa pada siklus ke II yaitu mencapai rata-rata 78,57 Jadi dari hasil pengamatan dan refleksi di siklus II penggunaan model/gambar alat pencernaan makanan manusia dapat meningkatkan partisipasi aktif dan prestasi belajar siswa. Hal ini dikarenakan dengan menggunakan model/gambar alat pencernaan makanan manusia, siswa lebih tertarik dan mempunyai motivasi yang tinggi untuk belajar. Keunggulan yang ada perlu dipertahankan untuk mendukung peningkatan dalam penggunaan media pembelajaran selanjutnya. Sedangkan beberapa kelemahan dalam media pembelajaran audio visual perlu diperbaiki untuk pertemuan selanjutnya. Berdasarkan hasil tes dan hasil observasi dari siklus II yang telah terjadi peningkatan dari siklus I, peneliti dan guru sepakat bahwa penelitian ini tidak dilanjutkan ke siklus III.

Penerapan model/gambar alat pencernaan makanan manusia pada siklus I dilakukan dalam dua kali pertemuan, tetapi di dalam pelaksanaannya belum tercipta peningkatan partisipasi aktif dan prestasi belajar siswa secara maksimal, maka peneliti sepakat untuk melanjutkan pada siklus berikutnya yaitu siklus II. Siklus demi siklus terbentuk untuk memberikan perbaikan dan perbandingan di dalam pembelajaran agar partisipasi aktif dan prestasi belajar lebih meningkat sesuai dengan apa yang diharapkan peneliti.

Dari pernyataan tersebut dapat disimpulkan bahwa mata pelajaran IPA dengan menggunakan model/gambar alat pencernaan makanan manusia ini dapat memberi kemudahan bagi siswa dalam memahami materi yang diberikan guru. Dalam pembelajaran siklus I masih ada siswa yang kurang dapat memahami materi pelajaran, permasalahan yang diberikan oleh guru serta belum semua siswa menunjukkan partisipasi aktif selama proses pembelajaran dengan menggunakan pemanfaatan lingkungan sekolah ini. Akan tetapi setelah siklus II para siswa berangsur-angsur dapat memahami materi, serta hampir semua siswa berpartisipasi aktif selama 
proses pembelajaran dengan menggunakan model/gambar alat pencernaan makanan manusia.

Hasil penelitian tindakan siklus I dan II dengan penggunaan pemanfaatan lingkungan sekitar sekolah menunjukkan adanya peningkatan terhadap aktivitas belajar siswa. Peningkatan terjadi pada observasi siklus II di mana dalam observasi ini yang diamati adalah partisipasi aktif siswa. Dari hasil observasi diperoleh data aktivitas siswa (Tabel 3.3).

Tabel 3.3 Peningkatan Partisipasi Aktif Siklus I dan Siklus II

\begin{tabular}{|l|l|l|}
\hline \multirow{2}{*}{\multicolumn{1}{|c|}{ Indikator }} & \multicolumn{2}{|l|}{ Siklus } \\
\cline { 2 - 3 } & I & II \\
\hline Mendengarkan Penjelasan & 9 & 17 \\
\hline Mencatat penjelasan & 10 & 21 \\
\hline Memperhatikan pembelajaran & 14 & 16 \\
\hline Bertanya & 8 & 15 \\
\hline Menjawab pertanyaan & 11 & 15 \\
\hline Mengeluarkan Pendapat & 5 & 9 \\
\hline Menghargai Pendapat teman & 13 & 20 \\
\hline Mampu menjelaskan kembali & 3 & 6 \\
\hline
\end{tabular}

Berdasarkan hasil observasi yang dapat dilihat dari tabel di atas dapat dilihat adanya peningkatan frekuensi dari siklus I sampai ke siklus II. Setiap indikator masing-masing siklus juga mengalami peningkatan. Pada siklus I dan siklus II peningkatan partisipasi siswa yang paling tinggi adalah mencatat penjelasan, karena terjadi peningkatan sebesar 13,75\% dan peningkatan partisipasi aktif siswa yang paling rendah adalah indikator mampu menjelaskan kembali, karena hanya terjadi peningkatan sebesar 3,75 \%.

Jadi dapat disimpulkan bahwa dengan model/gambar alat pencernaan makanan manusia dalam mata pelajaran IPA dapat meningkatkan partisipasi aktif siswa dalam proses pembelajaran. Untuk membuktikannya dapat dilihat dalam Tabel 3.3. Tabel 3.3. Perbandingan partisipatif per siklus.

\begin{tabular}{|l|l|l|}
\hline \multirow{2}{*}{ Aspek yang diamati } & \multicolumn{2}{|c|}{ \% Partisipasi Aktif } \\
\cline { 2 - 3 } & Siklus 1 & Siklus 1 \\
\hline Mendengarkan Penjelasan & $42,85 \%$ & $80,95 \%$ \\
\hline Mencatat penjelasan & $47,61 \%$ & $100 \%$ \\
\hline Memperhatikan pembelajaran & $66.6 \%$ & $76,19 \%$ \\
\hline Bertanya & $38,09 \%$ & $71,42 \%$ \\
\hline Menjawab pertanyaan & $52,3 \%$ & $71,42 \%$ \\
\hline Mengeluarkan pendapat & $23,8 \%$ & $42,85 \%$ \\
\hline Menghargai pendapat teman & $61,90 \%$ & $95,23 \%$ \\
\hline Mampu menjelaskan kembali & $14,28 \%$ & $28,57 \%$ \\
\hline
\end{tabular}

Pada indikator mendengarkan penjelasan persentase siswa dalam kelas pada siklus I sebesar $42,85 \%$ dan pada siklus II sebesar 80,95\%. Pada diagram di atas menunjukkan bahwa partisipasi aktif siswa untuk mendengarkan penjelasan guru dari siklus I ke siklus II persentasenya meningkat.

Pada indikator mencatat penjelasan persentase siswa dalam kelas pada siklus I sebesar 47,61\% dan pada siklus II sebesar $100 \%$. pada diagram di atas menunjukkan bahwa partisipasi siswa dari siklus I ke siklus II terjadi peningkatan persentase siswa yang sangat signifikan, karena siswa mulai dapat mengerti dan lebih mudah menangkap pembelajaran yang disampaikan menggunakan pemanfatan lingkungan sekolah, sehingga siswa dapat mencatat inti dari penjelasan guru pada setiap materi yang disampaikan.

Pada indikator memperhatikan pembelajaran persentase siswa dalam kelas pada siklus I sebesar 66,66 \% dan pada siklus II sebesar 76,19 \%. Pada diagram di atas menunjukkan bahwa terjadi peningkatan partisipasi aktif siswa untuk memperhatikan penjelasan guru dari siklus I ke siklus II, karena siswa menjadi tertarik dengan menggunakan (solusi).

Pada indikator bertanya persentasae siswa dalam kelas pada siklus I 38,09 \% dan pada siklus II sebesar 71,42 \%. Pada diagram di atas menunjukkan bahwa partisipasi aktif siswa untuk mendengarkan penjelasan guru dari siklus I ke siklus II juga mengalami peningkatan meskipun dalam persentase yang kecil. Hal ini terjadi karena adanya keengganan dan ketakutan siswa dalam bertanya, tetapi dengan adanya perubahan media yang digunakan guru dalam mengajar sedikit banyak mengubah siswa untuk lebih aktif dalam bertanya.

Pada indikator menjawab pertanyaan persentase siswa dalam kelas pada siklus 1 sebesar 52,38\% dan pada siklus II sebesar $71,42 \%$. Pada diagram di atas menunjukkan bahwa partisipasi aktif siswa untuk menjawab pertanyaan dari siklus I ke siklus II persentasenya meningkat.

Pada Indikator mengeluarkan pendapat persentase siswa dalam kelas pada siklus I sebesar 23,8\% dan pada siklus II sebesar 42,85 \%. Pada diagram di atas menunjukkan bahwa partisipasi aktif siswa untuk mengeluarkan pendapat dari siklus I ke siklus II persentasenya meningkat meskipun belum semua siswa dapat melakukannya.

Pada indikator menghargai pendapat teman persentase siswa dalam kelas pada siklus I sebesar 61,9\% dan pada siklus II sebesar 95,2\%. Pada diagram di atas menunjukkan bahwa partisipasi aktif siswa untuk menghargai pendapat teman dari siklus I ke siklus II persentasenya meningkat.

Pada indikator refleksi/mampu menjelaskan kembali persentase siswa dalam kelas pada siklus I sebesar 14,2\% dan pada siklus II sebesar 28,57\%. Pada diagram di atas menunjukkan bahwa partisipasi aktif siswa untuk refleksi/menjelaskan kembali dari siklus I ke siklus II persentasenya meningkat.

Penilaian yang digunakan pada setiap siklus adalah dengan menggunakan tes dan dilaksanakan pada setiap akhir siklus dengan soal-soal yang sesuai dengan materi yang diberikan kepada siswa. Hal ini dilakukan untuk mengukur sejauh mana siswa dapat menguasai materi yang telah disampaikan menggunakan model / gambar. Hasil penelitian tindakan siklus I dan II dengan penggunaan pemanfaatan lingkungan sekolah menunjukkan adanya peningkatan terhadap prestasi belajar siswa.

Dari pernyataan tersebut, dapat disimpulkan bahwa dengan menggunakan model/gambar alat pencernaan makanan manusia dapat menaikkan ingatan 
yang berarti dapat meningkatkan pestasi beajar siswa. Peningkatan prestasi belajar siswa dapat dilihat pada Gambar 3.1.

Setelah dilakukan penelitian yang dimulai dari tahapan siklus I, sampai pada tahapan siklus II dapat dilihat adanya peningkatan partisipasi aktif dan prestasi belajar siswa dengan menggunakan model /gambar. Berdasarkan pemaparan prestasi belajar di atas dapat diberikan penjelasan bahwa telah terjadi peningkatan prestasi belajar siswa dari siklus I mencapai rata-rata $68,76 \%$ naik menjadi rata-rat 78,57 \% pada tahap siklus II. Dari rata-rata tersebut dapat diketahui peningkatan rata-rata 9,81 \% dari siklus I ke siklus II. Dapat disimpulkan bahwa dengan penggunaan model /gaambar pada mata pelajaran IPA dapat meningkatkan prestasi belajar siswa. Peningkatan prestasi belajar dapat dilihat pada Gambar 3.2.

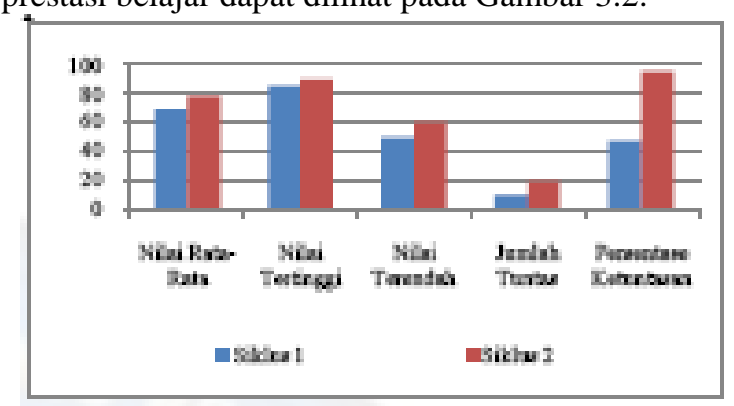

Gambar 3.2. Grafik peningkatan prestasi

Peningkatan rata-rata nilai hasil belajar dari siklus I sebesar 68,76 sedangkan pada siklus II meningkat menjadi sebesar 78,57. Peningkatan nilai tertinggi yang diperoleh siswa dari siklus I sebesar 85 sedangkan pada siklus II meningkat menjadi sebesar 90. Peningkatan nilai terendah yang diperoleh siswa dari siklus I sebesar 50 sedangkan pada siklus II meningkat menjadi sebesar 60. Peningkatan jumlah tuntas individu / siswa yang mencapai Kriteria Ketuntasan Minimal (KKM) dari siklus I sebesar 10 siswa sedangkan pada siklus II meningkat menjadi sebesar 20 siswa. Peningkatan persentase ketuntasan individu. Siklus I terdapat 47,61\% siswa yang telah mencapai ketuntasan / mencapai Kriteria Ketuntasan Minimal (KKM). Sedangkan pada siklus II terdapat 95,23 \% siswa telah mencapai KKM.

\section{KESIMPULAN}

Berdasarkan hasil analisis data dan pembahasan yang telah peneliti lakukan, aktivitas belajar siswa Siswa kelas V di SD Inpres 118 Klamalu untuk mata pelajaran IPA, dapat ditarik kesimpulan sebagai berikut: 1. Penerapan pembelajaran dengan menggunakan model/gambar alat pencernaan makanan manusia dapat meningkatkan pemamhaman siswa akan hasil fotosintesi pada mata pelajaran IPA siswa kelas $\mathrm{V}$ dilihat dari adanya peningkatan persentase,
2. Peningkatannya dapat dilihat dari hasil observasi pada siklus I dan siklus II. Pada Aspek mendengarkan penjelasan siklus I sebesar 42,82 \% dan siklus II sebesar $80,95 \%$. Aspek mencatat penjelasan siklus 1 sebesar 47,61\% dan siklus II sebesar 100 \%. Aspek memperhatikan pembelajaran siklus I sebesar 66,66\% dan siklus II sebesar 76,19.\%. Aspek bertanya siklus I sebesar 38,09 \% dan pada siklus II sebesar 71,42\%. Aspek menjawab pertanyaan siklus I sebesar 52,38\% dan siklus II sebesar 71,42 \%. Aspek mengeluarkan pendapat siklus I sebesar 23,80.\% dan pada siklus II sebesar 42,85\%. Aspek menghargai pendapat teman siklus I sebesar 61,90 \% dan pada siklus II sebesar 95,2 \%. Aspek mampu menjelaskan kembali siklus I sebesar $14,2 . \%$ dan pada siklus II sebesar 28,57\%. Hal ini menunjukkan bahwa terjadi peningkatan terhadap partisipasi aktif siswa pada Standar Kompetensi Menangani mata pelajaran IPA. Pemanfatan model/gambar alat pencernaan makanan manusia juga dapat meningkatkan hasil belajar pada mata pelajaran IPA di kelas. Peningkatan hasil belajar ini dapat dilihat dari adanya perubahan nilai rata-rata yang diperoleh siswa pada setiap akhir siklus. Nilai rata-rata yang diperoleh siswa pada siklus I sebesar 68,76 dan siklus II sebesar 78,57 Hal tersebut membuktikan bahwa dengan menggunakan pemanfatan lingkungan sekitar sekolah dapat meningkatkan prestasi belajar siswa.

\section{DAFTAR PUSTAKA}

Mulyasa. (2004). Menjadi Guru professional. Bandung: PT Remaja Rosdakarya.

Nana Sudjana. (2006). Penilaian Hasil Proses Belajar Mengajar. Bandung: PT Remaja Rosdakarya.

Riduwan. (2009). Skala Pengukuran Variabel-Variabel Penelitian. Bandung: Alfabeta.

Rochiati Wiriaatmadja. (2009). Metode Penelitian Tindakan Kelas. Bandung: PT Remaja Rosdakarya.

Slameto. (2010). Belajar dan Faktor-Faktor yang Mempengaruhi. Jakarta: Rineka Cipta.

Sugihartono. (2007). Psikologi Pendidikan. Yogyakarta: UNY .Press.

Suharsimi Arikunto. (2009). Dasar-dasar Evaluasi Pendidikan (Edisi Revisi, cetakan 7). Jakarta: Bumi Aksara

Suharsimi Arikunto, dkk. (2013). Penelitian Tindakan Kelas. Jakarta : Bumi Aksara.

Sumadi Suryabrata. (2006). Psikologi Pendidikan. Jakarta: PT Raja Grafindo Persada.

Suryobroto. (1997). Proses Belajar Mengajar di Sekolah. Jakarta: PT Rineka Cipta.

Susilo. (2007). Panduan Penelitian Tindakan Kelas. Yogyakarta: Pustaka Book Publlisher. 